\title{
Chapter 12 \\ Sustainable Use and Development of Forests and Forest Soils: A Resume
}

\author{
Andreas Bolte, Joachim Block, Johannes Eichhorn, Tanja G. M. Sanders, \\ and Nicole Wellbrock
}

\subsection{Introduction}

Environmental conditions determine forests' species composition, structure, and growth. Only with profound knowledge of these factors we can sustainably preserve and utilize forest ecosystems and their services. In order to gain this knowledge, we need to assess and monitor these ecosystems systematically. This knowledge was gained through two National Forest Soil Inventories (NFSI I and II) reflecting climate and weather conditions, as well as the deposition regime of nutrients and pollutants to German forests. Additionally, plots of the German Intensive Forest Monitoring (Level II), part of the International Co-operative Programme on Forests (ICP Forests), are included. Human activities resulting in greenhouse gases and air pollutant emissions are changing the physical and chemical growth conditions of individual trees and whole forests. The same applies to forest management due to, e.g., changes of the tree species composition, timber use, and liming. The forest soil condition bears witness of all these different natural and anthropogenic impacts. Therefore, care and conservation of forest soils are fundamental elements of a sustainable use of forest ecosystems besides sustainable and environmentally responsible forest management and timber utilization (BMEL 2015).

The first NFSI (NFSI I) studied the morphological, physical, and chemical status of German forest soils within the assessment period 1989-1992. A repetition after 15 years allows an insight in the temporal dynamics of forest soil conditions and

\author{
A. Bolte $(\bowtie) \cdot$ T. G. M. Sanders $\cdot$ N. Wellbrock \\ Thünen Institute of Forest Ecosystems, Eberswalde, Germany \\ e-mail: andreas.bolte@thuenen.de; tanja.sanders@thuenen.de; nicole.wellbrock@thuenen.de \\ J. Block \\ Research Institute for Forest Ecology and Forestry Rheinland-Pfalz, Trippstadt, Germany \\ J. Eichhorn \\ Northwest German Forest Research Institute, Göttingen, Germany \\ e-mail: johannes.eichhorn@nw-fva.de
}


their spatial patterns due to comparable sampling and analysis methods (see Chap. 1). Integration of the assessment of crown condition, forest nutrition, stand structure, and forest vegetation at the same samples plots provided a valuable and unique opportunity to evaluate the options and limitations of human utilization of forest ecosystems at a national scale.

In the following chapters, main results of the NFSIs, complemented by Level II, and their implications for sustainable forest management as well as forest and environmental policies in Germany are discussed and evaluated.

\subsection{Clean Air Policies and Forest Liming Take Effect Against Soil Acidification}

After the acknowledgment of lake and stream acidification found in large areas of Scandinavia in the mid-1970s (Almer et al. 1974), and the observation of forest decline at the end of this decade, the effects of acidifying sulfur and nitrogen deposition on forests, forest soils, and their chemical status, as well as on forest nutrition, moved in the focus of politics and scientists. A deep-reaching acidification and base cation depletion, the mobilization of root-toxic aluminum ion in the soil solution, and a deficiency of magnesium, calcium, and phosphorus nutrition were identified as serious impacts on forest soils and ecosystems (e.g., Ulrich 1986b; Hüttl and Schaaf 1997; see also Chap. 3; Carreira et al. 1997). The establishment and development of clean air policies on both the international scale [Convention of Long-Range Transboundary Air Pollution CLRTAP, UNECE (1979)] and the national scale [Large Combustion Plant Directive in 1983, 13. BImSchV, BR (1983)] have significantly reduced emissions, in particular of acidifying sulfur oxide $\left(\mathrm{SO}_{x}\right.$, Fig. 12.1).

Successful measures starting in the early 1980s included the removal of sulfur from waste gases of coal power plants and the introduction of catalyzers for motor vehicles in the Federal Republic of Germany (FRG). Contrasting policies of the German Democratic Republic (GDR) regime and neighbor countries (CSSR, Poland) during the 1960s to 1980 s led to regionally high deposition of sulfur oxide and base-rich fly ash emitted by lignite combustion in particular of coal power plants. Whereas fly ash deposition buffered acid deposition in less and mid-distant areas to power plants (Hofmann et al. 1990), remote and elevated regions like the Ore Mountains with considerably lower ash deposition received extremely high and unbuffered sulfur oxide loads resulting in extensive forest damages (Zimmermann et al. 2002), comparable to regions with high sulfur oxide emissions in West Germany like the Harz and the Fichtel Mountains (Matzner et al. 2004). After the reunification in 1990, consistent clean air policies were implemented throughout Germany. As a result sulfur and total acid deposition strongly decreased throughout Germany (Fig. 12.1). However, considerably less reduction is visible for the emission and deposition of acidifying nitrogen 

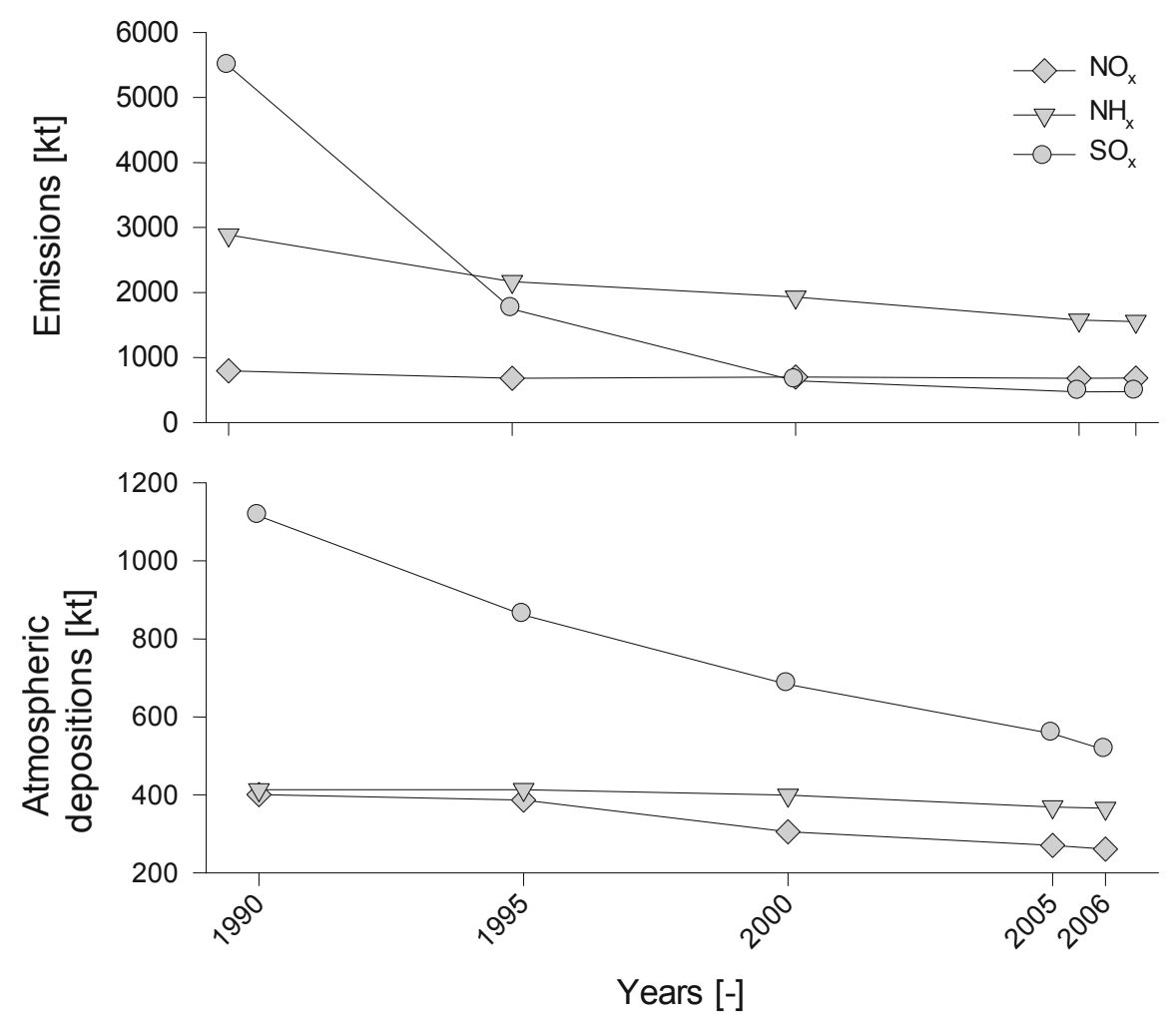

Fig. 12.1 Temporal trend (1990/NFSI I to 2006/NFSI II) of air pollutant $\left(\mathrm{NH}_{x}, \mathrm{NO}_{x} \mathrm{SO}_{x}\right)$ emissions (above, data source: UBA 2018) and total deposition in forests (below, modelled values; see Chap. 2)

compounds $\left[\mathrm{NO}_{x}, \mathrm{NH}_{x}\right.$ (Fig. 12.1)] (UBA 2013), leading to the initiation of the National Emission Ceilings Directive (NECD, 2016/2284/EU) in order to monitor the impact of acidifying and eutrophying compounds. In 2015 acidifying nitrogen contributed far more to the exceedance of critical loads for acidity $\left(\mathrm{CLF}_{\mathrm{aci}}\right)$ than sulfur (see Chap. 2).

At a local scale, forest liming is a technical measure to preserve sensitive forest soils from acidification (see Chap. 2), in addition to forest transformation activities (see Sect. 12.9). Since the beginning of the 1980s, forest sites in several German regions on both public and private forest land have been repeatedly limed, generally financed, or subsidized by public sources.

The results of the NFSIs reveal the success of these measures displaying an increase of soil $\mathrm{pH}$ values, not only in the organic layer but also in the mineral topsoil (see Chap. 4; Fig. 12.2). Only on limed forest sites, this is linked to a raise of base saturation in the upper layers of the mineral soil (Fig. 12.2) due to a surplus of calcium carbonate. This underlines the benefits of forest liming, in particular on soils with a high sensitivity of acidification 


\section{NFSI plots non-limed}

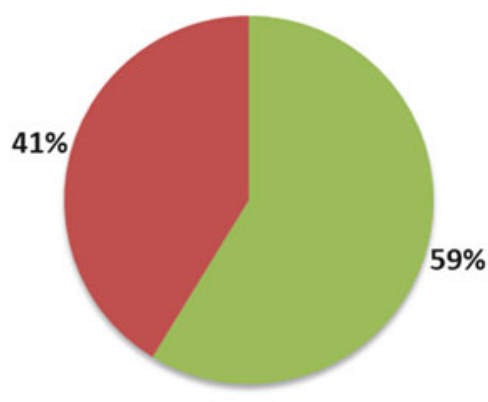

in $\mathrm{pH}(\mathrm{H} 2 \mathrm{O})$ value increase

n $\mathrm{pH}(\mathrm{H} 2 \mathrm{O})$ value decrease
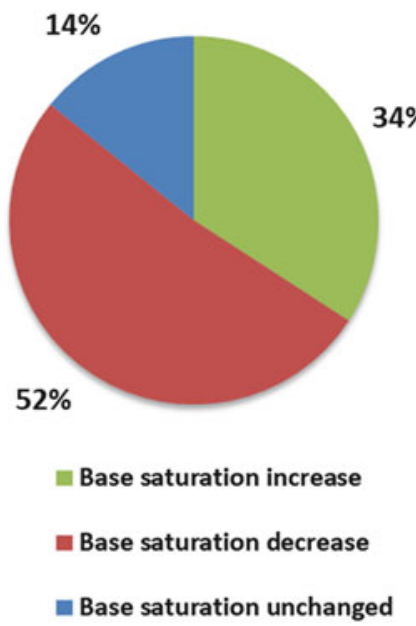

NFSI plots limed

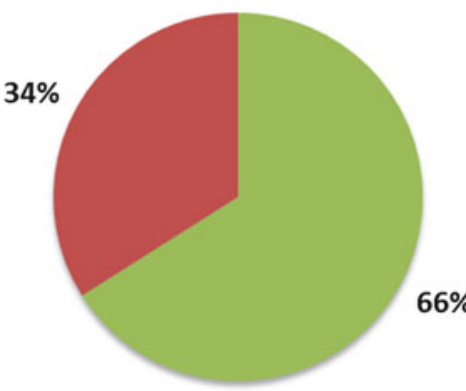

In $\mathrm{pH}(\mathrm{H} 2 \mathrm{O})$ value increase

$$
\text { a } \mathrm{pH}(\mathrm{H} 2 \mathrm{O}) \text { value decrease }
$$

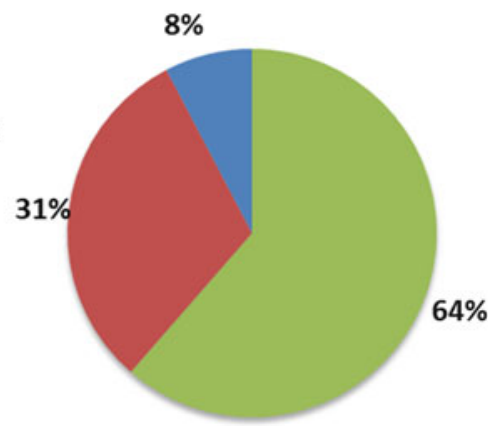

$$
\begin{aligned}
& \text { Base saturation increase } \\
& \text { Base saturation decrease } \\
& \text { Base saturation unchanged }
\end{aligned}
$$

Fig. 12.2 Changes of soil $\mathrm{pH}$ (in $\mathrm{H}_{2} \mathrm{O}$, above) and base saturation (below) in NFSI plots in the top mineral soil (10-30 cm depth) from NFSI I to NFSI II, non-limed (left) and limed (right)

We can conclude that clean air policies have been successful in terms of reducing the acidifying sulfur input in forest ecosystems, but efforts have to be increased to reduce nitrogen emissions, to lower their contribution to soil acidification and eutrophication (see Sect. 12.3). Forest liming of soils with considerable acidification is furthermore recommended to balance negative impacts on soil functioning, the vitality, and growth of forests. Both clean air policies and forest liming contributed considerably to the improvement of forest conditions and forest soils in times of forest decline, as well as to the prevention of further decline dynamics in Germany. 


\subsection{Nitrogen Eutrophication Remains Challenging}

Eutrophication of terrestrial ecosystems occurs due to the enrichment of priory limiting nutrients within the soil or a water body (Bobbink et al. 2010) and is still considered of having major impact on forests and forest soils. While in forest ecosystems often a natural, site-related limitation of nitrogen $(\mathrm{N})$ supply prevails, enhanced N deposition can induce nutrition imbalance (Oren and Schulze 1989; Schulze et al. 1989), i.e., a relative deficiency of other nutrients compared to nitrogen (Vitousek et al. 1997; Aber et al. 1998; Waldner et al. 2015), or it can improve N availability for trees, thus leading to increased foliar $\mathrm{N}$ concentrations (Tietema and Beier 1995). The inclination of the balance is plaid by deposition of both reduced and oxidized $\mathrm{N}$ compounds $\left(\mathrm{NO}_{x}, \mathrm{NH}_{x}\right)$, with the maximum uptake capacity for nitrogen reached at saturation (Ågren and Bosatta 1988; Aber et al. 1989; De Vries and Schulte-Uebbing 2019). Due to this, Eichhorn (1995) and Cole (1992) define nitrogen saturation as a status at which nitrogen input from deposition and mineralization exceed the retention capacity, and high nitrate leaching occurs ( $>5 \mathrm{~kg} \mathrm{ha}^{-1} \mathrm{a}^{-1}$, Block et al. 2000; $>10 \mathrm{~kg} \mathrm{ha}^{-1} \mathrm{a}^{-1}$; Vanguelova et al. 2010). This can also affect species composition of forest ground vegetation including the loss of rare species adapted to nitrogen-poor site conditions (Bobbink et al. 1998). Already an exceedance of a nitrogen deposition rate of $10-15 \mathrm{~kg} \mathrm{ha}^{-1} \mathrm{a}^{-1}$ can change forest floor species composition, increase susceptibility to pathogens, and vary the mycorrhiza regime (Bobbink et al. 2010).

Varying from modelled deposition rates at the NFSI sites (see Chap. 1 and Sect. 12.2), oxidized nitrogen $\left(\mathrm{NO}_{x}-\mathrm{N}\right)$ deposition further decreased during the period from 2002-2004 to 2012-2014 at the Intensive Forest Monitoring (Level II) sites, whereas reduced nitrogen $\left(\mathrm{NH}_{4}-\mathrm{N}\right)$ remained constant (Thünen Institute 2018). Mean total nitrogen deposition rates in Germany ranged between $10.6 \mathrm{~kg} \mathrm{ha}^{-1} \mathrm{a}^{-1}$ and $40.7 \mathrm{~kg} \mathrm{ha}^{-1} \mathrm{a}^{-1}$ (median $19.7 \mathrm{~kg} \mathrm{ha}^{-1} \mathrm{a}^{-1}$ ) in the period from the first (1990) to the second NFSI (2007) (see Chap. 5). Compared to other European countries, forests in Germany were therefore among the more severely polluted in Europe (Michel and Seidling 2016) with regions exceeding $50 \mathrm{~kg}^{\circ} \mathrm{ha}^{-1}{ }^{\circ}$ year $^{-1}$ (Meesenburg et al. 2005, 2016).

At NFSI sites, extreme exceedances $\left(>10 \mathrm{~kg} \mathrm{ha}^{-1} \mathrm{a}^{-1}\right)$ of critical loads for eutrophying nitrogen $\left(\mathrm{CL}_{\text {nut }}(\mathrm{N})\right.$; see Chap. 2) were observed on $85 \%$ of the sites in 1990 with a reduction to less than $50 \%$ in 2006 and less than $20 \%$ in 2015 (Table 12.1).

Table 12.1 Exceedance risk of eutrophying $\mathrm{N}\left(\mathrm{CL}_{\text {nut }}(\mathrm{N})\right.$, Ex. exceedance, Pot. Ex. potential exceedance) on NFSI plots in 1990, 2006, and 2015

\begin{tabular}{l|r|r|r}
\hline Classes $\left(\mathrm{kg} \mathrm{ha}^{-1} \mathrm{a}^{-1}\right)$ & 1990 & 2006 & 2015 \\
\hline No exceedance & 0.1 & 0.4 & 1.1 \\
\hline Pot. Ex. $\leq 10$ & 2.9 & 11.9 & 19.4 \\
\hline Pot. Ex. $>10$ & 3.4 & 2.3 & 1.0 \\
\hline Ex. $\leq 10$ & 8.7 & 36.6 & 59.1 \\
\hline Ex. $>10$ & 84.9 & 48.8 & 19.4 \\
\hline
\end{tabular}

Potential exceedance is calculated from the conservative approach with $\mathrm{N}_{\text {crit }}=0.2-0.4 \mathrm{mg}^{-1} \mathrm{~N}$ 
Nevertheless, sites with no exceedance are still rare. $\mathrm{CL}_{\text {nut }}(\mathrm{N})$ exceedances at the time of the NFSI II (2006) were found to increase the occurrence of nitrophilic plant species in montane Norway spruce forests, particularly competitive on eutrophic sites (Ziche et al. 2016).

Within the period nitrogen stocks in forest soils increased in the top mineral soil layer (significantly in $0-5 \mathrm{~cm}$ soil depth, slightly in 5-10 cm soil depth). The decrease of nitrogen stock in the layers below $30 \mathrm{~cm}$ may be caused by nitrate leaching or gaseous nitrogen losses. Forest soil liming, in particular when repeated, tends to facilitate the increase of nitrogen stock in the mineral soil (Melvin et al. 2013) and may result in nitrate leaching (Durka and Schulze 1992).

Overall, elevated nitrate leaching $\left(>5 \mathrm{~kg} \mathrm{ha}^{-1} \mathrm{a}^{-1}\right)$ is not expected at the vast majority of NFSI sites (see Chap. 5). However, it is possible on several N-saturated sites with continuously high $\mathrm{N}$ deposition or soils with low buffer capacity (UBA 2013). Excess nitrogen nutrition can be observed in Scots pine and oak and to a lesser extent in Norway spruce and European beech. Foliar nitrogen concentration increased in spruce and beech between the NFSI I (1990) and NFSI II (2006) with soil liming showing no distinct effect. With a balanced supply of nutrients being important for plant growth and performance, a high nitrogen status can be linked to nutrition deficiency, in particular of phosphorus $(\mathrm{P})$ in all major tree species and potassium $(\mathrm{K})$ in spruce and beech on one quarter of the sampled sites (see Chap. 8; Braun et al. 2010).

Nitrogen deposition led to a distinct nitrogen eutrophication of forest ecosystems in parts of Germany. Heterogeneous spatial patterns of forest ecosystems with and without nitrogen eutrophication may also be due to varying, distinct nitrogen losses in the past, linked to the practice of litter raking inducing enormous nitrogen exports (up to $1.7 \mathrm{t} \mathrm{N} \mathrm{ha}^{-1} \mathrm{a}^{-1}$, Kreutzer (1972)), as well as clear-cuts, and stand disturbances stimulating the decomposition of soil organic matter. Nitrogen oversupply (SRU 2015) has several negative effects on forest biodiversity, partly on tree nutrition, and under condition of $\mathrm{N}$ saturation, it induces undesired nitrogen outputs, e.g., nitrate leaching into the groundwater and emission of nitrous oxide from the soil into the atmosphere. Due to this, the reduction of nitrogen emissions, in particular of ammonia, should have a particularly high priority in clean air policies, i.e., compliance with emission standards according to the multicomponent protocol of the UN/ECE convention on Long-Range Transboundary Air Pollution (CLRTAP) and the EU National Emission Ceilings Directive (EU NEC Directive).

\subsection{Nutrient Sustainability Limits Biomass Harvest Options}

Nitrogen $(\mathrm{N})$, phosphorus $(\mathrm{P})$, magnesium $(\mathrm{Mg})$, potassium $(\mathrm{K})$, and calcium (Ca) are macronutrients crucial for tree growth, and their deficiency can limit terrestrial ecosystems functioning (Ellenberg et al. 1986). Harvest losses of nutrients, 


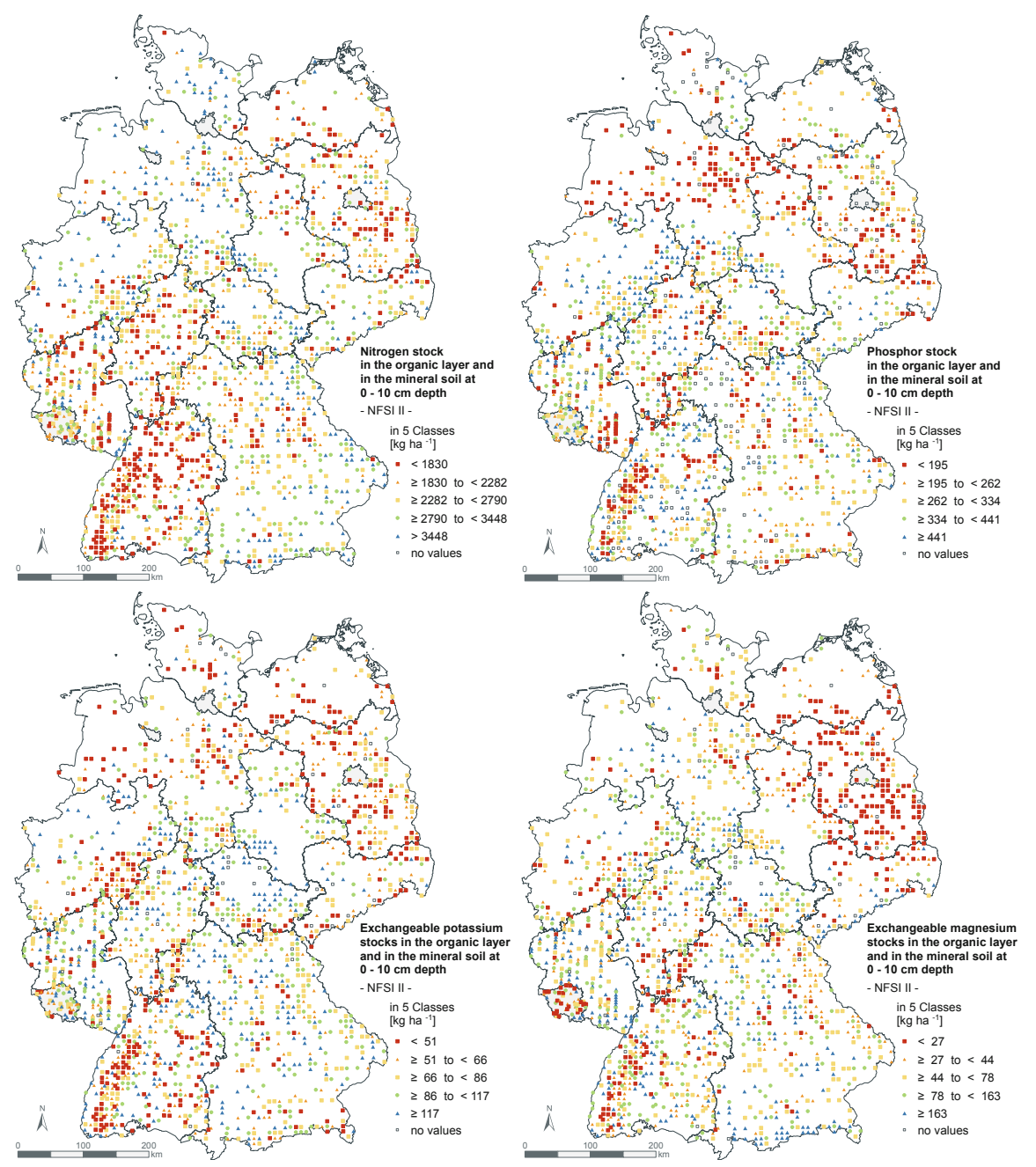

Fig. 12.3 Total nitrogen ( $\mathrm{N}$, above left) and phosphorus ( $\mathrm{P}$, above right) stocks, as well as exchangeable potassium ( $\mathrm{K}$, below left) and magnesium $(\mathrm{Mg}$, below right) in the organic layer and mineral top soil (down to $10 \mathrm{~cm}$ depth)

not balanced by atmospheric deposition, can only be resupplied through weathering of soil minerals. However, liming of an overall of $21 \%$ of the NFSI II sites, with $51 \%$ being acid-sensitive, changed the base saturation and in particular $\mathrm{Ca}$ availability considerably (see Chaps. 2 and 4).

Below average $\mathrm{N}, \mathrm{P}, \mathrm{Mg}$, and $\mathrm{K}$ stocks are visible in the organic and the mineral soil layer down to $10 \mathrm{~cm}$ depth in large parts of the northeastern lowlands (Fig. 12.3). However, late Pleistocene sites in eastern Schleswig-Holstein and northern Mecklenburg-West Pomerania are an exception with higher values. Above average nutrient stock is found in most areas of central and southern Germany, with low 
Table 12.2 Percentage (\%) of NFSI II plots with nutrient deficiency (incl. latent range)/luxury nutrition (surplus range) based on foliar threshold values, according to Göttlein (2015); all deficiency percentage values $>15 \%$ in bold

\begin{tabular}{l|l|l|l|l|l|l}
\hline & $\mathrm{N}$ & $\mathrm{P}$ & $\mathrm{K}$ & $\mathrm{Ca}$ & $\mathrm{Mg}$ & $\mathrm{S}$ \\
\hline Norway spruce & $9 / 29$ & $\mathbf{2 0} / 12$ & $\mathbf{2 2} / 9$ & $2 / \mathbf{4 3}$ & $6 / \mathbf{2 4}$ & $\mathbf{4 3} / 0$ \\
\hline Scots pine & $5 / \mathbf{5 4}$ & $\mathbf{1 9 / 1}$ & $13 / 1$ & $6 / 20$ & $\mathbf{2 5} / 4$ & $13 / 0$ \\
\hline European beech & $2 / \mathbf{2 6}$ & $\mathbf{6 1} / 1$ & $\mathbf{2 9} / 7$ & $\mathbf{1 7 / 2 6}$ & $\mathbf{2 7 / 3 6}$ & $\mathbf{4 6} / 1$ \\
\hline Oak species & $1 / \mathbf{5 5}$ & $\mathbf{3 8} / 7$ & $10 / 8$ & $\mathbf{1 6} / \mathbf{2 6}$ & $\mathbf{1 6} / 5$ & $0 / 0$ \\
\hline
\end{tabular}

values in the Black Forest, several sites in the Rhine-Main area, the Palatinate Forest (low N, P), eastern North Rhine-Westphalia (low K), and the Saarland region (low $\mathrm{Mg}$ ). A high amount of nutrients were transferred from the humus layer to the mineral soil between the periods of both NFSIs due to a shift of organic matter (Grüneberg et al. 2014; see Chap. 5), thus facilitating nutrient uptake of trees.

Foliar nutrient concentration of the major tree species is low in $\mathrm{P}$ (all species) and $\mathrm{S}$ (European beech, Norway spruce) at a larger number of sites. Moreover, K deficiency is particularly visible at several spruce and beech sites. Overall, forest foliar nutrition is following the sequence European beech $>$ Norway spruce $>$ Oak spec. $>$ Scots pine (Table 12.2). In contrast, nitrogen nutrition is mostly luxurious and often induces $\mathrm{P}$ deficiency relative to $\mathrm{N}$ concentration (high $\mathrm{N} / \mathrm{P}$ ratio; see Chap. 8; Braun et al. 2010; Sardans et al. 2016). Many forest sites have a limited natural supply of $\mathrm{Ca}, \mathrm{Mg}$, and $\mathrm{K}$, which is only supplied through mineral weathering. Ecosystem balances of these important nutrients and base cations are often negative partially due to their export by drainage water in relation to a surge of accompanying mobile anions like nitrate and sulfate in the soil solution (see Chap. 3; Ulrich 1986b; Likens et al. 1996).

Due to this sensitive balance in nutrient, harvest intensity, in particular extended harvest of biomass, must be carefully adjusted to the specific site conditions and the potential for replacing exported nutrients (Block and Meiwes 2013). Whole-tree harvesting (WTH, i.e., total biomass harvest above ground) which is rarely practiced in Germany exports the nutrient-rich tree compartments like bark, branches, and often needles or leaves from the forest. Thus, WHT should be restricted to sites with a sufficient nutrient provision ensuring the replacement of lost nutrients and sustainable site productivity.

\subsection{Forest Soils Absorb Heavy Metals}

Both, geogenic concentration of parent material and atmogenic deposition, determine the concentration of heavy metals ( $\mathrm{As}, \mathrm{Pb}, \mathrm{Cd}, \mathrm{Cr}, \mathrm{Cu}, \mathrm{Ni}, \mathrm{Hg}, \mathrm{Zn}$ ) in forest soils. Significant deposition effects, particularly a variance in top soil concentration, were observed for lead $(\mathrm{Pb})$, cadmium $(\mathrm{Cd})$, and mercury $(\mathrm{Hg})$, whereas such effects are less evident for arsenic (As) and copper $(\mathrm{Cu})$. Soil concentrations of the other elements 

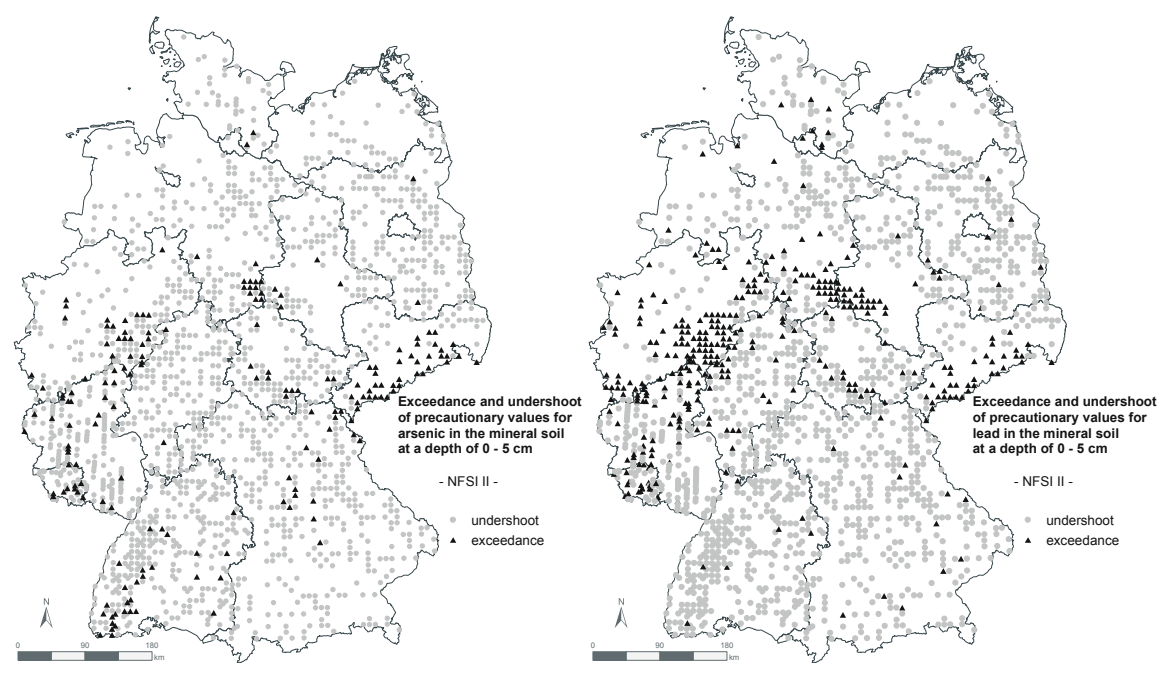

Fig. 12.4 Exceedance of precautionary values for arsenic (As, left) and lead ( $\mathrm{Pb}$, right) in the upper mineral soil $(0-5 \mathrm{~cm}$ depth)

[chromium $(\mathrm{Cr})$, nickel $(\mathrm{Ni})$, zinc $(\mathrm{Zn})]$ are mainly determined by geogenic base concentration (see Chap. 6; Luster et al. 2006). In forest soils, heavy metals are absorbed either by mineral surfaces (following the sequence $\mathrm{Cd}$, $\mathrm{Zn}<\mathrm{Cu}<\mathrm{Ni}$, $\mathrm{Cr}<\mathrm{Pb}$ ) or by complexation with humic substances in the organic soil compounds (stable complexes, $\mathrm{Pb}, \mathrm{Cr}, \mathrm{Ni}$, and $\mathrm{Cu}$; weak complexes, $\mathrm{Cd}$ and $\mathrm{Zn}$, König et al. 1986).

The heavy metal concentration $(\mathrm{Pb}, \mathrm{Cd}, \mathrm{Cr}, \mathrm{Cu}, \mathrm{Zn})$ in the organic layer decreased significantly from the first (1990) to the second (2006) NFSI ranging from $-33 \%$ $(\mathrm{Pb})$ to $-11 \%(\mathrm{Zn})$. This indicates a decreased deposition of these elements between both NFSIs as the decrease was lower $(-2 \%)$ in humus storage. An indication for a translocation of heavy metals into the mineral soil is missing, except for the relatively mobile $\mathrm{Cd}$. The only element which increased within the soil concentration is $\mathrm{Hg}$, although deposition has decreased in central Europe (Ilyin et al. 2016).

Only arsenic (As) with $11.2 \%$ and lead $(\mathrm{Pb})$ with $22.1 \%$ exceed the precautionary values according to the Federal Soil Protection Act (BBodSchV) at a national scale. Such critical values are mainly recorded in specific regions like the Ore Mountains $(\mathrm{As}, \mathrm{Pb})$, the Harz, and the Rhenish Slate Mountains $(\mathrm{Pb})$, resulting from both mining activity over the past century (Fig. 12.4) (Medyńska-Juraszek and Kabała 2012; Perković et al. 2017) and elevated atmospheric contamination. For Pb, past atmospheric inputs of leaded gasoline still play an important role as shown by isotope analyses within the French forest monitoring network (Hernandez et al. 2003).

Heavy metals are mainly absorbed in the organic compounds of the humus layer and in particular in the mineral soil (Luster et al. 2006). Therefore, a critical translocation within the ecosystem and a migration of these toxic elements into the groundwater are prevented. All silvicultural operations increasing and stabilizing the soil organic compound are thus recommended. These include low-disturbance stand 
management without clear-cuts and mechanical soil treatments. Liming can stabilize the soil organic matter (see Sect. 12.7) and prevent soil acidification (see Sect. 12.2) as an additional measure to keep and develop the absorptive function of forest soils for heavy metals. Nevertheless, all emission reduction options should be used in order to further reduce or even stop future heavy metal emissions. In doing so, special attention should be paid to mercury $(\mathrm{Hg})$ due to its increasing concentration in forest soils.

\subsection{Organic Pollutants (POPs) Persist Long Term in Forest Soils}

Persistent organic pollutants (POPs) can have harmful effects on humans and the environment paired with a low decomposition rate. These substances can accumulate in various environmental compartments, particularly in soils and sediments. POPs include polycyclic aromatic hydrocarbons (PAHs), polychlorinated biphenyls (PCBs), dichlorodiphenyltrichloroethane (DDT), and hexachlorobenzene (HCB) emitted for several decades and deposited throughout Germany (see Chap. 8).

In general, low concentrations are visible for the investigated POPs in German forest soils. For PAHs and PCBs, lower concentrations than the precautionary values of the German soil protection legislation (BBodSchV) were found. Densely industrialized and urbanized regions show comparatively enhanced PAHs and PCBs values, e.g., in vicinity of brown-coal strip-mining areas (Aichner et al. 2015; Pandelova et al. 2018). The long persistence of POPs in forest soils can be seen for DDx applied as pesticide in the 1980s and still detected in the organic layer, particularly in the Eastern Federal States. The deposition and concentration of POPs are not significantly linked to forest type and environmental factors but on the presence and distance of mostly local or regional emission sources (see Chap. 7; Aichner et al. 2013).

It is difficult to rule out deposition from various sources completely. However, significant efforts have to be taken in order to reduce any additional deposition of POPs in forest ecosystems due to their decade long persistence with the ecosystems. The application of pesticides with persistent organic compounds in forests should be strictly minimized and restricted to cases where other options are not available. Benefits of POP-pesticide application have to be carefully balanced against the threats. Since the concentration of most POPs is linked to the soil organic concentration (SOC) of the organic layer and the top mineral soil, high-disturbance stand management and soil treatments leading to decomposition of soil organic matter should be handled with care. 


\subsection{Carbon Sequestration in Forest Soil Supports Climate Protection}

Forest and forest soils in Germany sequester 52-58 $\mathrm{Tg}$ (= million $\mathrm{t}$ ) $\mathrm{CO}_{2}$-equivalent per year (reference period 1990 to 2012, year 2015) and thus play an important role in climate protection (Wellbrock et al. 2017; UBA 2017). Including the benefit of wood products from forest utilization, an additional emission amount of $36 \mathrm{Tg} \mathrm{CO}_{2}$ equivalent is annually avoided within Germany due to the substitution of fossil fuel through firewood (energetic substitution), approximately $30 \mathrm{Tg} \mathrm{CO}_{2}$ equivalent by the substitution of energy-intensive materials by wood products and material (material substitution) and $3 \mathrm{Tg} \mathrm{CO}_{2}$ equivalent through increased wood products storage (WBAE/WBW 2017). Thus, forest and sustainable forest utilization amounts to far more than $100 \mathrm{Tg} \mathrm{CO}_{2}$-equivalet of actual yearly greenhouse gas mitigation achievements in Germany. However, in contrast to the forest carbon sink status of forests in Germany, large-scale deforestation and forest degradation in other parts of the world result in a global net emission of $4900 \mathrm{Tg} \mathrm{CO}_{2}$-equivalent per year (year 2010, Tubiello et al. 2015).

The organic and the mineral layer (up to $90 \mathrm{~cm}$ depth) stored $1023 \mathrm{Tg} \mathrm{C}$ (year 2012) and thus represent the second largest carbon pool in forests after forest biomass (1149 $\mathrm{Tg} \mathrm{C}$ ). In total, German forest stands and soils contained approx. $2384 \mathrm{Tg}$ C after $1951 \mathrm{Tg}$ C in 1990 (Fig. 12.5), (Wellbrock et al. 2017).

In mineral forest soils (up to $30 \mathrm{~cm}$ depth), the annual increase of carbon storage amounts to $0.4 \mathrm{t} \mathrm{ha}^{-1} \mathrm{a}^{-1}$ between 1990 and 2006. Concurrently the organic layer lost $0.02 \mathrm{t} \mathrm{C} \mathrm{ha}^{-1} \mathrm{a}^{-1}$ (see Chap. 5; Grüneberg et al. 2014). This relates to a yearly carbon sink rate of $15 \mathrm{Tg} \mathrm{CO}_{2}$-equivalent for the top soils down to $30 \mathrm{~cm}$ depth throughout Germany.
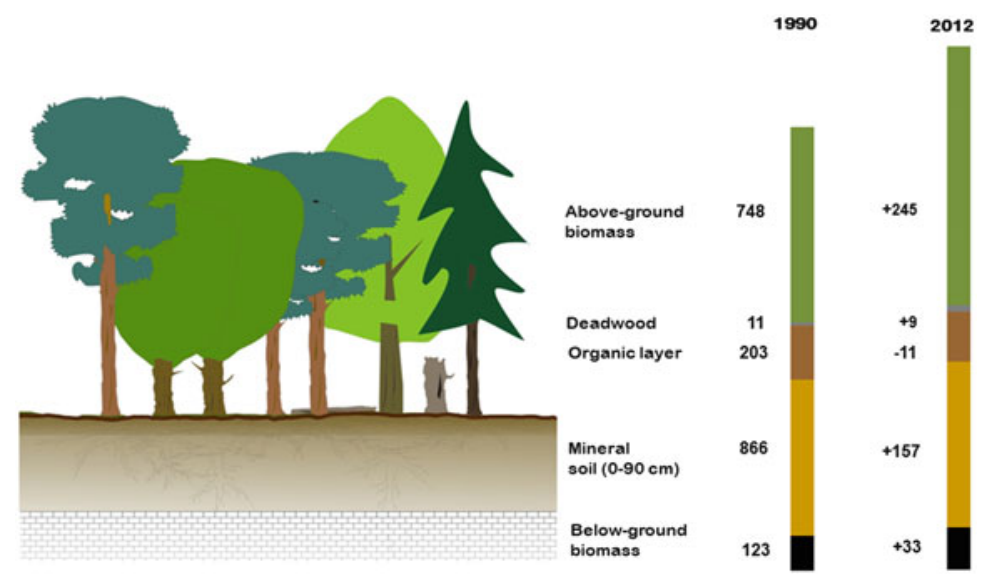

Fig. 12.5 Carbon storage [in $\mathrm{Tg} C$ ] in forests and forest soils in Germany according to the five carbon pools to be reported in greenhouse gas reporting under LULUCF (Wellbrock et al. 2017) 
These results reveal that the sustainable management of forests in Germany over the last decades led to carbon sequestration both in forest and forest soils as well as in wood products. This is complemented with a considerable avoidance of greenhouse gas emissions due to a substitution of fossil fuels and other energy-intensive materials. Thus, the combination of site-adapted, sustainable forest management combined with the construction of long-lived wood materials and products and the option of a final, energetic use (cascade utilization) provides evident benefits for climate protection and should be continued. Large-scale restrictions for forest management or even the ban of timber use would counteract climate protection through decreased energetic and material substitution of wood and wood products (WBAE/WBW 2017), as well as wood imports from larger areas outside Germany (Schulze et al. 2016). Forest transformation with an increase of deciduous tree species and soil liming has no significant effect on the amount of carbon in the organic layer and the mineral soil. However, both management activities contribute to a shift of carbon from the organic layer to the mineral soil, thus possibly stabilizing carbon storage in forest soils. The advantage of an increased share of deciduous trees, however, has to be traded off against the disadvantage of a lower demand of hardwood for wood products and material substitution (Frühwald and Knauf 2013) and the susceptibility of some of these species to climate extremes (see Chap. 11). Different intensities of practiced continuous cover forestry (without clearcuts) are not significantly affecting carbon sequestration in forest soils (Mund and Schulze 2006; Jandl et al. 2011; Wäldchen et al. 2013; Grüneberg et al. 2013).

Thus, sustainable forestry in Germany produced considerably positive effects on climate protection, and there are overall benefits of continuing the existing practice of forest management. Timber should be used as efficiently as possible, and its use for wood products should always be preferred to an energetic use. Initiatives aiming at the implementation of multiple and cascading uses of timber should be supported through structural measures and incentives (WBAE/WBW 2017). Due to the benefits of wood use, harvest restrictions have to be carefully considered.

\subsection{Atmospheric Pollution Interacts with Climate Change Impacts}

Impacts of air pollutants and atmospheric deposition on trees can change the response to climate and especially to extreme weather events like heat waves and droughts (Paoletti et al. 2007). Bytnerowicz et al. (2007) mention an increased sensitivity of trees with nitrogen oversupply to late frost, pathogens, and drought (Dziedek et al. 2016). Moreover, a shallower rooting after soil acidification can induce higher drought sensitivity (Ulrich 1986a). Drought is affecting trees and forests by its timing, duration, and intensity (see Chap. 3); a soil water availability of less than $20 \%$ can induce severe consequences for forest ecosystem productivity and integrity (Granier et al. 2007), as well as for young trees' survival (Bolte et al. 2016). 
The crown condition assessment at NFSI sites provides relevant insights into the risk status of forests to air pollution and climatic impacts (see Chap. 11).

Norway spruce trees, with excessive nitrogen needle concentrations, show a significantly higher defoliation, while their condition is better at limed sites. Norway spruce growing on soils of low water storage capacity and high evapotranspiration potential exhibit more often needle losses than those on other sites. Spruce mortality is often high for several years after warm and dry years or storm events likely linked to increased bark beetle infestations (Bolte et al. 2014). Dominating risks for spruce are intensifying nitrogen eutrophication and climate warming with accompanying biotic threats.

For European beech, similar impact factors on crown condition are evident due to a distinct defoliation peak after the drought in 2003 (Seidling 2007; Eichhorn and Roskams 2013); however, pathogens do not play an important role and overall mortality is low.

Crown condition of oak species is similarly affected by climate warming showing higher defoliation values after the 2003 drought year. Oaks show and have been showing the highest defoliation of all four major tree species in Germany for decades. This is mainly due to pathogen impact of leaf-eating insect communities stimulated by warmer and longer growing seasons (see Chap. 11) which can produce a feedback loop on carbon cycling with enhanced releases of $\mathrm{CO}_{2}$ and dissolved organic carbon (DOC) from forest soils after decomposition rise of organic matter (Arnold et al. 2016).

These results show that a significant lowering of greenhouse gas emissions is urgently needed to limit ongoing climate change to an extent $\left(\leq 2{ }^{\circ} \mathrm{C}\right.$ aim) to which forests in Germany are able to adapt. This is in particular needed, as past and current air pollutants have predisposed many forests to decline.

\subsection{Forest Transformation Affects Forest Soils Positively}

Forest transformation from mono-species coniferous forests with Norway spruce and Scots pine to broadleaved and mixed forests is a common practice of forest management in Germany and changed forest structures considerably. Forest cover with spruce and pine has decreased by 329,000 ha, whereas areas with European beech, oak, and other broadleaved species increased by 315,000 ha from 2002 to 2012 (BMEL 2015).

This resulted in positive effects for forest soils: on average broadleaved forests exhibit lower soil acidification and higher base saturation compared to coniferous forests and sequester more organic matter and carbon (SOC) in the mineral soil (see Chaps. 2, 4, and 6). The immobilization of SOC in mineral soil horizons counteracts disturbances of the organic layer and top soil with SOC losses. Moreover, organically bound nutrients are better available for root uptake.

Due to the strongly prevailing economic role of coniferous timber for the wood processing sector (Dieter and Janzen 2015) and the required diversification of risks 
for climate change impacts (Kolström et al. 2011), mixed forests are preferable with an adequate proportion of coniferous trees (WBAE/WBW 2017) adaptive to future climate and site conditions. Structural measures and incentives should aim at increasing the mixed forest area in Germany including stress-tolerant native species like Silver fir but also non-native species like Douglas and Grand fir. Therefore, ungulate browsing adverse to mixed stand regeneration and development as well as species diversity (Ammer 1996; Schulze et al. 2014) has to be controlled.

\subsection{Conclusions and Outlook}

Anthropogenic induced site variations due to acid and nitrogen deposition, as well as a changing climate, have modified forest soil traits more rapidly than expected, thus producing forests and forest soils with a changed ecosystem service and risk portfolio.

The results of the repeated NFSIs produced new opportunities to assess the effects of environmental change and management on forests and forest soils. For the first time, status variation of forest soils and corresponding forest ecosystem traits were analyzed in a systematic and representative manner for Germany on a national and regional scale. Both the number of 1900 forest sites and the extent of the various parameters for crown condition, forest stand, vegetation, nutrition, and soil status have provided novel options to link their results with the findings of the Intensive Forest Monitoring (ICP Forests, Level II), in particular for nutrient balances and soil processes, as well as with model approaches as demonstrated in this volume, e.g., for nitrogen cycling and budgeting (see Chap. 5). New possibilities also address the integrative assessment of forest and agricultural sites after the Agricultural Soil Inventory for Germany (Bach et al. 2011) will be finalized. This will enable insights in the sustainable development of soil organic carbon (SOC) in forest and agricultural soils with varying environmental conditions and land uses and could also allow for an economic evaluation of different land-use scenarios.

The NFSI is an important monitoring instrument of the national forest assessment system in Germany which is codified in the Federal Forest Act (FFA, Bundeswaldgesetz $\S$ 41a: Walderhebungen) and of specific meaning for political consultation of the evaluation of forest and soil status changes, in their extent, dynamic, and regional patterns based on time series produced by repeated sampling of the same forest sites with comparable methodologies. Based on the NFSI results, a repetition period of 15-20 years is recommended (Fig. 12.6). Due to this, a new federal ordinance for the third NFSI is currently prepared for the period 2022-2024 in order to picture the dynamic development of soils by monitoring.

The findings show that both, further efforts to reduce air pollution and the consequent continuation of a sustainable and soil conservative forest management, are needed to maintain and develop vital and productive forests with fertile soils. Therefore, the advancement and implementation of politics and structural measures are important. The achievements in reducing the acid burden through clean air 


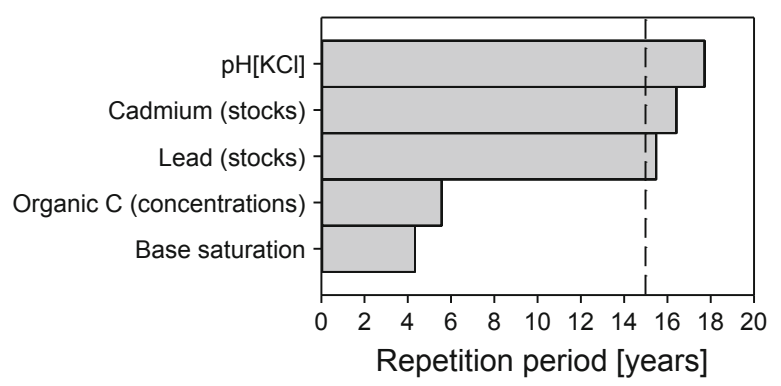

Fig. 12.6 Repetition period for significant changes of different soil status parameters based on analyses of the first and second NFSI. Lead $(\mathrm{Pb})$, cadmium $(\mathrm{Cd})$ storages are derived from the organic layer, whereas $\mathrm{pH}(\mathrm{KCl}), \mathrm{SOC}$ content, and base saturation are related to the upper mineral soil (to $10 \mathrm{~cm}$ depth). The dashed line indicates a period of 15 years above which significant changes can be expected for all shown parameters

policies and forest soil liming demonstrate the options of concerted political action and local management. Only the results of the NFSI could provide evidence for these achievements.

The NFSI also demonstrates the successful collaboration of the German Federal and the Federal State authorities in this nation-wide assessment of forest and soil status both on a national and regional scale. Not all research questions can be answered with the NFSI approach of a systematical grid sampling. Thus, several detailed questions like the impacts of forest soil compaction by heavy harvest technique require additional research with alternative approaches. However, the integration of results of additional soil research in the NFSI evaluation provides an advanced benefit.

Finally, the major gain of the NFSI emerges from the attention and implementation of the results in policy, administrative processes, and forest management.

\section{References}

Aber JD, Nadelhoffer KJ, Steudler P, Melillo JM (1989) Nitrogen saturation in northern forest ecosystems. Bioscience 39(6):378-386. https://doi.org/10.2307/1311067

Aber JD, McDowell W, Nadelhoffer K, Magill A, Berntson G, Kamakea M, McNulty S, Currie W, Rustad L, Fernandez I (1998) Nitrogen saturation in temperate forest ecosystems-hypotheses revisited. Bioscience 48(11):921-934. https://doi.org/10.2307/1313296

Ågren GI, Bosatta E (1988) Nitrogen saturation of terrestrial ecosystems. Environ Pollut 54(3-4):185-197. https://doi.org/10.1016/0269-7491(88)90111-X

Aichner B, Bussian B, Lehnik-Habrink P, Hein S (2013) Levels and spatial distribution of persistent organic pollutants in the environment: a case study of German forest soils. Environ Sci Technol 47(22):12703-12714. https://doi.org/10.1021/es4019833

Aichner B, Bussian BM, Lehnik-Habrink P, Hein S (2015) Regionalized concentrations and fingerprints of polycyclic aromatic hydrocarbons (PAHs) in German forest soils. Environ Pollut 203:31-39. https://doi.org/10.1016/j.envpol.2015.03.026

Almer B, Dickson W, Ekström C, Hörnström E, Miller U (1974) Effects of acidification on Swedish lakes. Ambio 3(1):30-36 
Ammer C (1996) Impact of ungulates on structure and dynamics of natural regeneration of mixed mountain forests in the Bavarian Alps. For Ecol Manag 88(1-2):43-53. https://doi.org/10.1016/ s0378-1127(96)03808-x

Arnold AIM, Grüning M, Simon J, Reinhardt AB, Lamersdorf N, Thies C (2016) Forest defoliator pests alter carbon and nitrogen cycles. R Soc Open Sci 3(10). https://doi.org/10.1098/rsos. 160361

Bach M, Freibauer A, Siebner C, Flessa H (2011) The German agricultural soil inventory: sampling design for a representative assessment of soil organic carbon stocks. Procedia Environ Sci 7:323-328. https://doi.org/10.1016/j.proenv.2011.07.056

Block J, Meiwes KJ (2013) Erhaltung der Produktivität der Waldböden bei der Holz-und Biomassenutzung. In: Bachmann G, König W, Utermann J (eds) Bodenschutz - Ergänzbares Handbuch der Maßnahmen und Empfehlungen für Schutz, Pflege und Sanierung von Böden, Landschaft und Grundwasser. Erich Schmidt Verlag, Berlin

Block J, Eichhorn J, Gehrmann J, Kölling C, Matzner E, Meiwes KJ, von Wilpert K, Wolff B (2000) Kennwerte zur Charakterisierung des ökochemischen Bodenzustandes und des Gefährdungspotentials durch Bodenversauerung und Stickstoffsättigung an Level II-Waldökosystem-Dauerbeobachtungsflächen. Bundesministerium für Ernährung. Landwirtschaft und Forsten, Bonn

BMEL (2015) The forests in Germany—selected results of the Third National Forest Inventory. BMEL, Berlin

Bobbink R, Hornung M, Roelofs JGM (1998) The effects of air-borne nitrogen pollutants on species diversity in natural and semi-natural European vegetation. J Ecol 86(5):717-738. https://doi.org/10.1046/j.1365-2745.1998.8650717.x

Bobbink R, Hicks K, Galloway J, Spranger T, Alkemade R, Ashmore M, Bustamante M, Cinderby S, Davidson E, Dentener F, Emmett B, Erisman JW, Fenn M, Gilliam F, Nordin A, Pardo L, de Vries W (2010) Global assessment of nitrogen deposition effects on terrestrial plant diversity: a synthesis. Ecol Appl 20(1):30-59. https://doi.org/10.1890/08-1140.1

Bolte A, Hilbrig L, Grundmann BM, Roloff A (2014) Understory dynamics after disturbance accelerate succession from spruce to beech-dominated forest-the Siggaboda case study. Ann For Sci 71(2):139-147. https://doi.org/10.1007/s13595-013-0283-y

Bolte A, Czajkowski T, Cocozza C, Tognetti R, de Miguel M, Pšidová E, Ditmarova L, Dinca L, Delzon S, Cochard H, Ræbild A, de Luis M, Cvjetkovic B, Heiri C, Müller J (2016) Desiccation and mortality dynamics in seedlings of different European beech (Fagus sylvatica L.) populations under extreme drought conditions. Front Plant Sci 7:1-12. https://doi.org/10. 3389/fpls.2016.00751

BR (1983) Dreizehnte Verordnung zur Durchführung des Bundes-Immissionsschutzgesetz (Verordnung über Großfeuerungsanlagen - 13. BImSchV). Bundesgesetzblatt 26, Bonn

Braun S, Thomas VF, Quiring R, Flückiger W (2010) Does nitrogen deposition increase forest production? The role of phosphorus. Environ Pollut 158(6):2043-2052. https://doi.org/10.1016/ j.envpol.2009.11.030

Bytnerowicz A, Omasa K, Paoletti E (2007) Integrated effects of air pollution and climate change on forests: a northern hemisphere perspective. Environ Pollut 147(3):438-445. https://doi.org/ 10.1016/j.envpol.2006.08.028

Carreira JA, Harrison AF, Sheppard LJ, Woods C (1997) Reduced soil P availability in a Sitka spruce (Picea sitchensis (Bong) Carr) plantation induced by applied acid-mist: significance in forest decline. For Ecol Manag 92(1-3):153-166. https://doi.org/10.1016/s0378-1127(96) 03914-x

Cole DW (1992) Nitrogen chemistry, deposition, and cycling in forests. In: Johnson DW, Lindberg SE (eds) Atmospheric deposition and forest cycling. Ecological Studies (Analysis and Synthesis), vol 91. Springer, New York, pp 150-213. https://doi.org/10.1007/978-1-4612-2806-6_6

De Vries W, Schulte-Uebbing L (2019) Impacts of nitrogen deposition on forest ecosystem services and biodiversity. In: Schröter M, Bonn A, Klotz S, Seppelt R, Baessler C (eds) Atlas of ecosystem services: drivers, risks, and societal responses. Springer International Publishing, Cham, pp 183-189. https://doi.org/10.1007/978-3-319-96229-0_29 
Dieter M, Janzen N (2015) Deutsches Cluster Forst und Holz im internationalen Wettbewerb. AFZ Wald 70(17):13-15

Durka W, Schulze E (1992) Hydrochemie von Waldquellen des Fichtelgebirges. Umweltwiss Schadst Forsch 4(4):217-226

Dziedek C, Hardtle W, von Oheimb G, Fichtner A (2016) Nitrogen addition enhances drought sensitivity of young deciduous tree species. Front Plant Sci 7. https://doi.org/10.3389/fpls.2016. 01100

Eichhorn J (1995) Stickstoffsättigung und ihre Auswirkungen auf das Buchenwaldökosystem der Fallstudie Zierenberg. Berichte des Forschungszentrum Waldökosysteme/A, vol 124. Research Centre for Forest Ecosystems of Göttingen University, Göttingen

Eichhorn J, Roskams P (2013) Assessment of tree condition. In: Ferretti M, Fischer R (eds) Forest monitoring - methods for terrestrial investigations in Europe with an overview of North America and Asia. Developments in Environmental Science, vol 12. Newnes, San Diego, pp 139167. https://doi.org/10.1016/B978-0-08-098222-9.00008-X

Ellenberg H, Mayer R, Schauermann J (1986) Ökosystemforschung: Ergebnisse des Sollingprojekts 1966-1986. Ulmer, Stuttgart

Frühwald A, Knauf M (2013) Verlust an Wertschöpfung und Klimaschutz droht. Holz-Zentralblatt 12:291-293

Göttlein A (2015) Grenzwertbereiche für die ernährungsdiagnostische Einwertung der Hauptbaumarten Fichte, Kiefer, Eiche, Buche. Allg Forst Jagdztg 186(5/6):110-116

Granier A, Reichstein M, Bréda N, Janssens I, Falge E, Ciais P, Grünwald T, Aubinet M, Berbigier P, Bernhofer C (2007) Evidence for soil water control on carbon and water dynamics in European forests during the extremely dry year: 2003. Agric For Meteorol 143(1-2):123-145. https://doi.org/10.1016/j.agrformet.2006.12.004

Grüneberg E, Schöning I, Hessenmöller D, Schulze ED, Weisser WW (2013) Organic layer and clay content control soil organic carbon stocks in density fractions of differently managed German beech forests. For Ecol Manag 303:1-10. https://doi.org/10.1016/j.foreco.2013.03.014

Grüneberg E, Ziche D, Wellbrock N (2014) Organic carbon stocks and sequestration rates of forest soils in Germany. Glob Chang Biol 20(8):2644-2662. https://doi.org/10.1111/gcb.12558

Hernandez L, Probst A, Probst JL, Ulrich E (2003) Heavy metal distribution in some French forest soils: evidence for atmospheric contamination. Sci Total Environ 312(1-3):195-219. https://doi. org/10.1016/s0048-9697(03)00223-7

Hofmann G, Heinsdorf D, Krauss H (1990) Wirkung atmogener Stickstoffeinträge auf Produktivität und Stabilität von Kiefern-Forstökosystemen. Beitr Forstwirtsch 24(2):59-73

Hüttl RF, Schaaf WW (1997) Magnesium deficiency in forest ecosystems. Nutrients in Ecosystems, vol 1. Springer Science \& Business Media, Dordrecht. https://doi.org/10.1007/978-94-0115402-4

Ilyin I, Rozovskaya O, Travnikov O, Varygina M, Aas W, Pfaffhuber KA (2016) Assessment of heavy metal transboundary pollution, progress in model development and mercury research. EMEP Status Report vol 2/2016. MSC-E \& CCC, Moscow, Russia \& Kjeller, Norway

Jandl R, Alm J, Vesterdal L, Olsson M, Weiss P, Sjögersten S, Rodeghiero M, Leifeld J, Hagedorn F, Bellamy P, Baritz R (2011) Soil carbon in sensitive European ecosystems: from science to land management-a summary. In: Jandl R, Rodeghiero M, Olsson M (eds) Soil carbon in sensitive European ecosystems. Wiley-Blackwell, Chichester, pp 267-281. https://doi.org/10. 1002/9781119970255.ch11

Kolström M, Lindner M, Vilén T, Maroschek M, Seidl R, Lexer MJ, Netherer S, Kremer A, Delzon S, Barbati A, Marchetti M, Corona P (2011) Reviewing the science and implementation of climate change adaptation measures in European forestry. Forests 2(4):961-982. https://doi. org/10.3390/f2040961

König N, Baccini P, Ulrich B (1986) Der Einfluß der natürlichen organischen Substanzen auf die Metallverteilung zwischen Boden und Bodenlösung in einem sauren Waldboden. J Plant Nutr Soil Sci 149(1):68-82. https://doi.org/10.1002/jpln.19861490109

Kreutzer K (1972) Über den Einfluß der Streunutzung auf den Stickstoffhaushalt von Kiefernbeständen (Pinus silvestris L.). Forstwiss Centralbl 91(1):263-270. https://doi.org/10. 1007/BF02741000 
Likens GE, Driscoll CT, Buso DC (1996) Long-term effects of acid rain: response and recovery of a forest ecosystem. Science 272(5259):244-246. https://doi.org/10.1126/science.272.5259.244

Luster J, Zimmermann S, Zwicky CN, Lienemann P, Blaser P (2006) Heavy metals in Swiss forest soils: modification of lithogenic and anthropogenic contents by pedogenetic processes, and implications for ecological risk assessment. In: Frossard E, Blum WEH, Warkentin BP (eds) Function of soils for human societies and the environment. Special Publications, vol 266. Geological Society, London, pp 63-78

Matzner E, Zuber T, Alewell C, Lischeid G, Moritz K (2004) Trends in deposition and canopy leaching of mineral elements as indicated by bulk deposition and throughfall measurements. In: Matzner E (ed) Biogeochemistry of forested catchments in a changing environment. Ecological Studies (Analysis and Synthesis), vol 172. Springer, Berlin, pp 233-250. https://doi.org/10. 1007/978-3-662-06073-5_14

Medyńska-Juraszek A, Kabała C (2012) Heavy metal pollution of forest soils affected by the copper industry. J Elem 17(3):441-451. https://doi.org/10.5601/jelem.2012.17.3.07

Meesenburg H, Mohr K, Dämmgen U, Schaaf S, Meiwes KJ, Horváth B (2005) Stickstoff-Einträge und -Bilanzen in den Wäldern des ANSWER-Projektes - Eine Synthese. Landbauforsch Volk 279:95-108

Meesenburg H, Ahrends B, Fleck S, Wagner M, Fortmann H, Scheler B, Klinck U, Dammann I, Eichhorn J, Mindrup M (2016) Long-term changes of ecosystem services at Solling, Germany: recovery from acidification, but increasing nitrogen saturation? Ecol Indic 65:103-112. https:// doi.org/10.1016/j.ecolind.2015.12.013

Melvin AM, Lichstein JW, Goodale CL (2013) Forest liming increases forest floor carbon and nitrogen stocks in a mixed hardwood forest. Ecol Appl 23(8):1962-1975. https://doi.org/10. 1890/13-0274.1

Michel AK, Seidling W (2016) Forest condition in Europe: 2016. Technical report of ICP Forests. Report under the UNECE Convention on Long-Range Transboundary Air Pollution (CLRTAP). BFW-Dokumentation. BFW Austrian Research Centre for Forests, Vienna

Mund M, Schulze ED (2006) Impacts of forest management on the carbon budget of European beech (Fagus sylvatica) forests. Allg Forst Jagdztg 177(3-4):47-63

Oren R, Schulze E-D (1989) Nutritional disharmony and forest decline: a conceptual model. In: Schulze E-D, Lange OL, Oren R (eds) Forest decline and air pollution: a study of spruce (Picea abies) on acid soils. Ecological Studies (Analysis and Synthesis), vol 77. Springer, Berlin, pp 425-443. https://doi.org/10.1007/978-3-642-61332-6_20

Pandelova M, Henkelmann B, Bussian BM, Schramm KW (2018) Results of the second national forest soil inventory in Germany-interpretation of level and stock profiles for PCDD/F and PCB in terms of vegetation and humus type. Sci Total Environ 610:1-9. https://doi.org/10.1016/ j.scitotenv.2017.07.246

Paoletti E, Bytnerowicz A, Andersen C, Augustaitis A, Ferretti M, Grulke N, Gunthardt-Goerg MS, Innes J, Johnson D, Karnosky D, Luangjame J, Matyssek R, McNulty S, Muller-Starck G, Musselman R, Percy K (2007) Impacts of air pollution and climate change on forest ecosystems-emerging research needs. Sci World J 7:1-8. https://doi.org/10.1100/tsw.2007.52

Perković I, Lazić A, Pernar N, Roje V, Bakšić D (2017) Forest soil pollution with heavy metals (Pb, $\mathrm{Zn}, \mathrm{Cd}$, and $\mathrm{Cu}$ ) in the area of the "French Mines" on the Medvednica Mountain, Republic of Croatia. Southeast Eur For 8(1):31-40. https://doi.org/10.15177/seefor.17-08

Sardans J, Alonso R, Janssens IA, Carnicer J, Vereseglou S, Rillig MC, Fernandez-Martinez M, Sanders TGM, Penuelas J (2016) Foliar and soil concentrations and stoichiometry of nitrogen and phosphorous across European Pinus sylvestris forests: relationships with climate, N deposition and tree growth. Funct Ecol 30(5):676-689. https://doi.org/10.1111/1365-2435.12541

Schulze ED, Lange OL, Oren R (1989) Forest decline and air pollution: a study of spruce (Picea abies) on acid soils. Ecological Studies (Analysis and Synthesis), vol 77. Springer, Berlin. https://doi.org/10.1007/978-3-642-61332-6

Schulze ED, Bouriaud O, Wäldchen J, Eisenhauer N, Walentowski H, Seele C, Heinze E, Pruschitzki U, Danila G, Marin G, Hessenmöller D, Bouriaud L, Teodosiu M (2014) Ungulate browsing causes species loss in deciduous forests independent of community dynamics and 
silvicultural management in Central and Southeastern Europe. Ann For Res 57(2):267-288. https://doi.org/10.15287/afr.2014.273

Schulze ED, Frör O, Hessenmöller D (2016) Externe ökologische Folgen von Flächenstilllegungen im Wald. AFZ Wald 15:24-26

Seidling W (2007) Signals of summer drought in crown condition data from the German Level I network. Eur J For Res 126(4):529-544. https://doi.org/10.1007/s10342-007-0174-6

SRU (2015) Towards an integrated approach for nitrogen. Partial translation of the special report "Nitrogen: Strategies for resolving an urgent environmental problem". German Advisory Council on the Environment (SRU), Berlin. https://www.umweltrat.de/SharedDocs/Down loads/EN/02_Special_Reports/2012_2016/2015_01_Nitrogen_Strategies_summary.pdf?_ blob=publicationFile\&v=3. Accessed 28 Mar 2019

Thünen Institute (2018) Belastung durch Luftverunreinigungen in Deutschland. https://blumwald. thuenen.de/level-ii/auswertungen/deposition/. Accessed 06/03/2018

Tietema A, Beier C (1995) A correlative evaluation of nitrogen cycling in the forest ecosystems of the EC projects NITREX and EXMAN. For Ecol Manag 71(1-2):143-151. https://doi.org/10. 1016/0378-1127(94)06091-v

Tubiello FN, Salvatore M, Ferrara AF, House JI, Federici S, Rossi S, Biancalani R, Golec RDC, Jacobs H, Flammini A, Prosperi P, Cardenas-Galindo P, Schmidhuber J, Sanchez MJS, Srivastava N, Smith P (2015) The contribution of agriculture, forestry and other land use activities to global warming, 1990-2012. Glob Chang Biol 21(7):2655-2660. https://doi.org/ $10.1111 / \mathrm{gcb} .12865$

UBA (2013) Genug getan für Mensch und Umwelt? - Wirkungsforschung unter der Genfer Luftreinhaltekonvention. Umweltbundesamt (UBA), Dessau-Roßlau

UBA (2017) Submission under the United Nations Framework Convention on Climate Change and the Kyoto Protocol 2017-National Inventory Report for the German Greenhouse Gas Inventory 1990-2015. Climate Change. Umweltbundesamt (UBA), Dessau-Roßlau

UBA (2018) National trend tables for the German atmospheric emission reporting 1990-2016. Umweltbundesamt. https://www.umweltbundesamt.de/themen/luft/emissionen-vonluftschadstoffen. Accessed 02/03/2017

Ulrich B (1986a) Die Rolle der Bodenversauerung beim Waldsterben: Langfristige Konsequenzen und forstliche Möglichkeiten. Forstwiss Centralbl 105(1):421-435. https://doi.org/10.1007/ BF02741750

Ulrich B (1986b) Natural and anthropogenic components of soil acidification. J Plant Nutr Soil Sci 149(6):702-717. https://doi.org/10.1002/jpln.19861490607

UNECE (1979) Convention on Long-Range Transboundary Air Pollution (CLRTAP). Geneva

Vanguelova EI, Benham S, Pitman R, Moffat AJ, Broadmeadow M, Nisbet T, Durrant D, Barsoum N, Wilkinson M, Bochereau F, Hutchings T, Broadmeadow S, Crow P, Taylor P, Houston TD (2010) Chemical fluxes in time through forest ecosystems in the UK-soil response to pollution recovery. Environ Pollut 158(5):1857-1869. https://doi.org/10.1016/j. envpol.2009.10.044

Vitousek PM, Aber JD, Howarth RW, Likens GE, Matson PA, Schindler DW, Schlesinger WH, Tilman D (1997) Human alteration of the global nitrogen cycle: sources and consequences. Ecol Appl 7(3):737-750. https://doi.org/10.2307/2269431

Wäldchen J, Schulze ED, Schöning I, Schrumpf M, Sierra C (2013) The influence of changes in forest management over the past 200 years on present soil organic carbon stocks. For Ecol Manag 289:243-254. https://doi.org/10.1016/j.foreco.2012.10.014

Waldner P, Thimonier A, Pannatier EG, Etzold S, Schmitt M, Marchetto A, Rautio P, Derome K, Nieminen TM, Nevalainen S, Lindroos AJ, Merila P, Kindermann G, Neumann M, Cools N, de Vos B, Roskams P, Verstraeten A, Hansen K, Karlsson GP, Dietrich HP, Raspe S, Fischer R, Lorenz M, Iost S, Granke O, Sanders TGM, Michel A, Nagel HD, Scheuschner T, Simoncic P, von Wilpert K, Meesenburg H, Fleck S, Benham S, Vanguelova E, Clarke N, Ingerslev M, Vesterdal L, Gundersen P, Stupak I, Jonard M, Potocic N, Minaya M (2015) Exceedance of critical loads and of critical limits impacts tree nutrition across Europe. Ann For Sci 72(7):929-939. https://doi.org/10.1007/s13595-015-0489-2 
WBAE/WBW (2017) Climate change mitigation in agriculture and forestry and in the downstream sectors of food and timber use. Berichte über Landwirtschaft - Sonderheft. Scientific Advisory Board on Agricultural Policy, Food and Consumer Health Protection (WBAE) and Scientific Advisory Board on Forest Policy (WBW) at the Federal Ministry of Food and Agriculture (BMEL), Berlin. https://doi.org/10.12767/buel.v1i1.175

Wellbrock N, Grüneberg E, Riedel T, Polley H (2017) Carbon stocks in tree biomass and soils of German forests. Cen Eur For J 63(2-3):105-112. https://doi.org/10.1515/forj-2017-0013

Ziche D, Michler B, Fischer HS, Kompa T, Höhle J, Hilbrig L, Ewald J (2016) Boden als Grundlage biologischer Vielfalt. In: Wellbrock N, Bolte A, Flessa H (eds) Dynamik und räumliche Muster forstlicher Standorte in Deutschland. Ergebnisse der Bodenzustandserhebung im Wald 2006 bis 2008. Thünen Report 43. Johann Heinrich von Thünen Institute, Federal Research Institute for Rural Areas, Forestry and Fisheries, Braunschweig, pp 292-342. https://doi.org/10.3220/ REP1473930232000

Zimmermann F, Lux H, Reuter F, Wienhaus O (2002) SO2 pollution and forest decline in the Ore Mountains-historical aspects, scientific analysis, future developments. In: Lomsky B, Materna J, Pfanz H (eds) SO2-pollution and forest decline in the ore mountains. Ministry of Agriculture of the Czech Republic, pp 86-116

Open Access This chapter is licensed under the terms of the Creative Commons Attribution 4.0 International License (http://creativecommons.org/licenses/by/4.0/), which permits use, sharing, adaptation, distribution and reproduction in any medium or format, as long as you give appropriate credit to the original author(s) and the source, provide a link to the Creative Commons licence and indicate if changes were made.

The images or other third party material in this chapter are included in the chapter's Creative Commons licence, unless indicated otherwise in a credit line to the material. If material is not included in the chapter's Creative Commons licence and your intended use is not permitted by statutory regulation or exceeds the permitted use, you will need to obtain permission directly from the copyright holder.

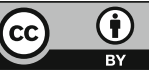

